\title{
OCCUPATIONAL STRESS OF ASSEMBLY LINE FEMALE WORKERS IN CONFECTIONERY WORK
}

\author{
Yuji Kondo,* Yoshio Sato,** Hideki Takashima,** Taichiro SIKI,** \\ Shunen INUI,** Hideaki ARACHI,* Noriyoshi YAMASHITA* \\ and Migiwa HosoKAWA***
}

\begin{abstract}
Concomitant with frequent occurrence of disorders of the neck, arm, hand and low back among assembly-line female workers in confectionery work, there is an increased number of patients with occupational cervicobrachial disorders and/or low back pain. In suspicion of the close correlation between the working conditions and development of these local disorders, a field study was undertaken. The following are the results obtained.

1) More than $90 \%$ of these assembly-line female workers consisted of inexperienced part-time employees, mostly of middle to old age.

2) They were engaged in decorating conveyor-carried cakes with cream and chocolate. The work necessitated repetitive movements of the upper limbs and concentration of visuosensory and nervous attention in a half-sitting slouching posture. This was considered to exert excess load on the local muscles and nervous and sensory systems.

3) The causes that intensified the local symptoms as pointed out by the workers consisted of (1) repetitive use of the arms and hands, (2) static posture during the work and (3) sustained standing position. Complaints of low back pain were conspicuous from the unsuitable height of a conveyor-belt.

4) Thirty five percent of the female workers needed medical treatment for cervicobrachial and/or low back pain.

5) The forced adaptation to the belt height, sustained unnatural working posture and the imposition of forced movements seemed to be the main factors in the onset of cervicobrachial and/ or low back pain in interrelation with working hours.

On the basis of these results, the work load on a machine-paced assembly-line was analyzed and the necessity of improvement of working conditions was discussed.
\end{abstract}

\section{I.はじめに}

生産様式のなかであ最も高い生産性をあげる方式の一

* 奈良県立医科大学衛生学教室

***京都工場保健会

*** 京都府立大学産業福祉学講夾 昭和58年10月 13 日受付

* Department of Hygiene, Nara Medical University

** Kyoto Industrial Health Association

*** Department of Occupational Welfare, Kyoto Prefecutural University

Received for publication, October 13, 1983
つに, コンベアを用いた流れ作業方式がある. コンベア を用いた作業方式は，生産速度の上昇および品質の安定 性の確保を通して高生産能率と大量生産飞最適な方法て あり，また製品の送りの自動化化よる人力節減や工程の 細分化によって，女子労働者を中心とした未熟練者の就 学を可能としてきた.このため，現代工業に和ける作業 形態のなかでも中心的なるのの一つになっている.

しかし，ュンベフ方式による作業は作業者火心身上の 多くの負担をあたらすことが知られている. 分業化隹よ って作業内容は学純化・標準化され，作業速度が機械的 
飞決められるなめ，作業者の作業姿勢や作業動作が拘束 され神経緊張が強くなりやすいまた，単調感や疲労伿 意感から作業意欲が低下するなどの精神衛生上の問題 中，反復動作之不良努势の連続からくる上肢，頸，背腰 部などの局所負担の問題が，これまでにも数多く指摘さ れている1-4.

コンベフ作業促事する作業者の頸肩腕障害や腰痛の

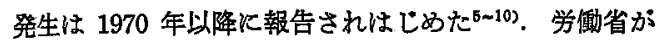
1974年に実施した「学働者の健康状況調查」112 は, 流れ

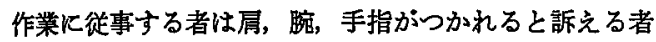
か，事務・管理・監視・一般作業洨事する者に比して 著しく多く，筋骨格系の疾患䍦患率も高くなっているこ とを示した。

顽肩踠障害の発生事例伔ついての研究報告として，前 田法弱電機器組立工場6)や紙巻きタバ製造工場の流れ 作業者》飞重症の患者が発生していることを報告し，労 儌負担との関連で発症要因を解析した。 また，細川18 は コンべフ方式による薬品包装作業者のなかに中・重应の 患者を見いだし，連続時間の短縮や作業方式の改善など の対策によって患者が減少したことを報告した，そのほ か，女子労働者の母性保護との関連で，コンベア作業は つわり症状や後期妊娠中䓯症の発現を高めるなどの悪影 㛭を与兄るとする報告むある ${ }^{12}$.

ンンベフ作業化批ける作業負担軽減と健康障害を発生 させない笔件の確保は学衝衛生上の重要な課題である. 本論文は、コンベアを用いた流れ作業方式による洋菓子 製造工場飞和ける頚眉腕障害中腰痛の実態を明らかにす るととすに，労㗢衙生的問題点を指摘しようとするすの である.

\section{II. 調査対象および方法}

本調査の調査対象は, デェレーションケーキ, ショー トケーキなどの洋菓子を製造する工場のコンベア作業方 式の仕上げ部門とそこに働いている女子作業者 174 名で ある.

調查内容は，作業内容，作業量，作業環境，作業姿斩 などについての労働条件調查，および質問紙法に上る健 隶謂查である.このうち，労㖶条件調査恃1981年 6 月か 57月にかけて行い，作業負担上の問題点について検討 を行ったまをた，健康調查については1981年 6 月に実施 した. 工場女子作業者総数 345 名のうち，流れ作業に從 事する 174 名を対象化して,身体疲学部位，作業状況，通 院・治療状況和よび発症要因に関する自記式質問秖調查 を行った，健康調查票の回收は 112 名であり，回收率は 64.4\% であったが，末回収者は仕上げ部門の特定ライ

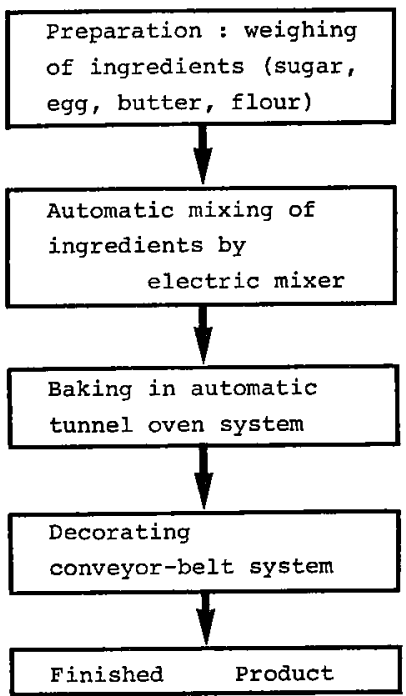

Fig.1. Manufacturing process of confectionery work.

ンに集中していたのでこのライン従事者を調查対象から 除外し，残りの 108 名について検討を加兄た（この場合 回収率は $62.1 \%$ である). 健康調查結果炕関連する訴え 率の差の検定には $\chi^{2}$-test (Yates の補正) を用いた.

\section{III. 作業概要と労働条件}

\section{1. 作業概要}

対象工場では，1952年に設立されて以来デコレーショ ソケーキやショートケーキなどの洋菓子を製造してい る. 1968年, 洋菓子製造工程にコンベア・システムが導 入され，焼成から仕上げまでを一貫したラインとし，そ の生産性を向上させ，近年企業規模の拡大をはじ急成 長をしてきた工場である。

洋菓子製造工程は Fig. 1 に示すように，原料のしこ み，準備，焼成，仕上げの 4 工程に分かれている。調査 対象となった仕上げ工程は，Fig.2 亿示すようなベルト コンベアによる流れ作業で，製品の種類，形状によって 数種のラインに分かれている.これらのコンベア面の高 さ怯, $70 \mathrm{~cm}$ と $75 \mathrm{~cm}$ の 2 種類が用いられていた. コン ベ面の幅はとすK $65 \mathrm{~cm}$ であった. 作業は, 各ライン ともコンベフで流れてくるカステラ台に対してクリー ム,フルーッ，チョコレート類で装飾をほどこし，完成 させるすのである. 1 テイン当り 20 名前後の女子が配 置されており、リリーフマンとして男性が $1 \sim 2$ 名配置 されている。作業量は1時間当りデコレーションケーが キ500 800個，ショートケーキは $6,000 \sim 8,000$ 個であ 
った。作業環境は，室温は $20^{\circ} \mathrm{C}$ に設定されており,コン ベア面の照度は 930 940 lx の範用で, 啯音は 75〜80 $\mathrm{dB}(\mathrm{A})$ であった。

\section{2. 作業動作・姿勢}

クリーム等で装飾する作業は，生クリームやバターク リームを充填したしぼり袋を両手掌で把み両手指のにぎ り動作によって，連続して適当な量を適正な場所にしぼ り出すくり返しであり，しぼり作業と呼ばれている.上 肢への重量負荷との関連でクリームが充填されたしばり 袋の平均重量をみると，生クリーム使用時では $600 \mathrm{~g}$,

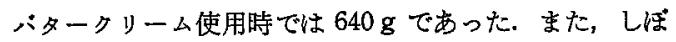
り袋に充媜されたクリームを使いはたすまでの時間は， 生クリームが $3 \sim 5$ 分であったのに対し，バタークリー ムは 5 ～6分と若干長くなっていた. 製造直後のクリー ム類の硬度は、バタークリームは生クリームに対してそ の硬度が通常数倍高いといわれている ${ }^{13)}$. この硬度の差 はしぼり作業に勒ける手指のにぎり力の差となっている ことが考えられる。

作業㛑勢は立位で，顔を製品の真上にもっていき，乙 ぼり袋の先を製品化密接させてしぼる作業である.その ために，上体とともに頸の前㑯度も深くなっていた。作 業者の平均身長は $153.2 \mathrm{~cm}$ であり，これら作業者の上 体前傾度の範网（肩峰点と腸稜点を結ぶ線が垂直線とな す角度) は $30^{\circ} \sim 75^{\circ}$, 形前傾度の範囲 (耳孔と第 7 頸椎 を結ぶ線が垂直線となす角度）は $30^{\circ} \sim 80^{\circ}$ であり，腕 の内角は $70^{\circ} \sim 110^{\circ}$ の䇺囲であった.

手指, 腕, 背腰部, 頸部の負担が大きい作業動作, 姿 勢であるといえよう (Fig.2).

\section{3. デコレーションケーキの作業内容}

デコレーションケーキ製造の作業内容を工程順に示す と次のと物りであった。

i ) 先頭作業: 作業者は 1 名. 暁成加ら移送されてき たケーキ台座をとり上け゚，側面，底紙をはがしてコンベ ア上に置く作業で, コンベアの流れの出発点である. 1 分間当りの送り個数は8ー12個であった．立位作業であ る.

ii）へたとり・サンド，台鉒り：スライサーを通過す ることによって自動的に 3 枚にスライスされたカステラ 台を1枚ずつコンベア上にひろげ, ヘラ（ナッペと呼ば れている）を用いて生クリームを塗布する作業でする. その後、スライス片を重ね，コンベアからとり上げコン ペア外に設置された涂布機にのせる。これによって自動 的にヶーキ傾面，上面に生クリームが塗布される.ここ には3人の作業者が配置されていた，作業者は手首，腰 の症状の訴えとともに「作業においたてられる」と訴え

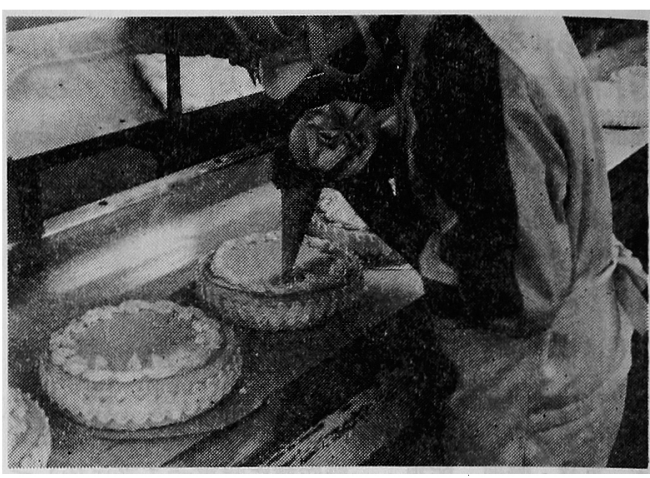

Fig. 2. Female workers decorating cakes with funnel-shaped bag on conveyor-belt.

ていた.

iii）修正作業：作業者 1 名. 塗布機による生クリーム の盗布が万遍なく行われているかをコンペア上で目視検 查を行いながら，ナッぺで修正していく作業である.

iv）線描き作業: 作業者 1 名. 生クリームの上にチョ コレート類が自動的に塗布された後にセロファン内のジ ヤム類でケーキ上面に細い波状しぼりが行われる.上体 の深い前傾で上肢全体を使ら作業であり，右上肢の負担 とともに腰への負担によると思われる訴えが認められ た.

v) 紙敷き作業：作業者 1 名. 右手でフライパン返し 様道具（スケッパー）を用いてケーキ台座をるち上げ， 左手でコンペフ上に円形紙を敷き，その上にヶーキ台座 を置く作業である．片手でケーキ台座を持ら上げるため 右手首のだるさ，痛みが訴えられていた。

vi）サイドしぼり，上しぽり作業：サイドしばりは3 〜 名で, コンベア上のケーキ台座を持ら上げ，上段テ ーブル（コンベフ面から 40 45cm 上，床面から115 $120 \mathrm{~cm}$ となる）に移し、ケー丰側面のしだり作業を行 う. 右上肢を肩位置まで水平にもっていき，手掌を上面 にしてしぼり袋をるち，前腕を上下に微動させながらし ぼりを行う．躬幹は側面に傾いた立位姿 势である，上 肢，頸，背腰部への負担が大きい作業である.上しばり は，サイドしぼりの後コンベアに移されたケーキ台座上 面に対し，生クリームを波状にしぼり出す作業であり， 4 名が配置されていた。 しぼりは主に右手のIII，IV，V 指を用いたにぎり動作によって行われていた，腕は空間 に固定し，一定の高さを保ちつつ正確に必要量をしぱ り，しばり袋 1 袋当り $5 \sim 6$ 分でクリーム補充のため 30 秒ほどラインを離れる動作のくり返しであった. 前傎努 勢からくる頸や腰背部の負担とともに, 粘性, 硬度の遣 いによってクリームしはりり相当な握力を必要とするた 
Table 1. Age distributions and length of employment and working hours of female assembly-line workers.

\begin{tabular}{cccccccc}
\hline $\begin{array}{c}\text { Age in years } \\
\text { Number of workers }\end{array}$ & -29 & $30-39$ & $40-49$ & $50-$ & NA & Total \\
\cline { 2 - 8 }$\%$ & 9 & 33 & 43 & 21 & 2 & 108 \\
\hline \hline Length of employment & 8.3 & 30.6 & 39.8 & 19.4 & 1.9 & 100 \\
\hline $\begin{array}{c}\text { Number of workers } \\
\%\end{array}$ & -2 yrs & $2-3$ & 4 & $5-9$ & 10 & NA & Total \\
\cline { 2 - 8 } & 26 & 50 & 16 & 13 & 1 & 2 & 108 \\
\hline \hline Working hours & 24.1 & 46.3 & 14.8 & 12.0 & 0.9 & 1.9 & 100 \\
Number of workers & $1.5 \mathrm{hrs}$ & $4 \mathrm{hrs}$ & $8 \mathrm{hrs}$ & & Total \\
$\%$ & \multicolumn{2}{c}{16} & 27 & 65 & & 108 \\
& 14.8 & & 25.0 & 60.2 & 100 \\
\hline
\end{tabular}

NA : no answer.

め手指への負理む小さくないと考えられた. また微細か つ機敏な上肢動作と視覚, 神経の集中が要求される作業 ですある.作業者の多くは「連続 20 30 分が限度であ る」と訴えていた.

vii）人形かざり，箱詰め作業：生クリームでの装飾が 終了した台座に対し，作業者 4 名でハラ型クリーム，人 形菓子をのせ完成する. その後, 箱詰めしてラインでの 作業は終了する.

一製品が仕上げ工程にのせられ，完成するまでの所要 時間は約 15 分であった。

\section{4. 労働条件}

工場の全作業者数は，男女あわせて 422 名（調查時） であった. 女子 345 名のらち 9 割以上にあたる 326 名が バート㕍用であった. 最近 4 年間の作業者数を 1978 年 を指数 100 としてみると，1979年 100,1980年 137, 1981 年には 170 に増大していた。

拘束時間は，冬場では 8 時 40 分 17 時 40 分の 9 時間 で,このうち 60 分休䅗. ただ夏場は 8 時 40 分 16 時 40 分の 8 時間拘束, 60 分休賏である. パート作業者の 作業時間は 90 分, 4 時間, 8 時間の作業時間帯から構 成されていた．昼食以外に定まった休毠時間はないが， コンペフラインは製造品目の切換党時（1日3品目）に 10 15分間停止するので，この時間が休息時間として利 用されていた。な和，作業中にトイレなどラインを離れ る際は、リリーフマンを呼んで交代することになってい る. 年間のらち繁忙期は，3月の「おひなさまケーキ」 の時期と 12 月の「クリスマスケーキ」の時期である. この時期になると, パート作業者む增し，午前 5 時から 午後 9 時 30 分までの 16 時間連続操業となる.

\section{IV. 労働負担に関する質問纸調査喆果}

\section{1. 作業者の年齢・作業従事年数, 就労条件}

仕上げ工瑅の流れ作業につく 174 名の女子のうち分析 対象とした 108 名の年龄，作業従事年数，作業時間を Table 1 飞示した. このらら 98 名 (96.1\%) がパート 雇用であった.

年龄は 19 56 歳に分布し，平均年龄は $40.8 \pm 4.0$ 葴 であった，30，40 歳が中心で，そのなかです 40 歳代が 全体の 39.8\% を占めていた，また，50歳以上は全体の $19.4 \%$ であった. 作業従事年数は平均で 2.3 年であり， 3 年末満の者が $70.4 \%$ と半数以上を占めていた. 10 年

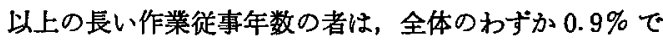
あった.

作業時間は，1日 8 時間勤務が全体の60.2\%を占め， 次いで 4 時間勤務 $25.0 \%, 90$ 分勤務 $14.8 \%$ であった。 4 時間勤務は， 9 時から 13 時までと 13 時から 17 時ま での 2 勤務帯からなり，90 分勤務は 11 時 30 分から 13 時までで，両勤務者とも8時間勤務者の昼食休秝時間帯 に重なるように設定されていた。

\section{2. コンベア面高}

対象とした 3 ラインに従事する作業者を，コンベア面 高 $75 \mathrm{~cm}$ と $70 \mathrm{~cm}$ の 2 群化分け，作業姿勢との関連で 検討した. I-Group はコンベア面高が $75 \mathrm{~cm}$ の 2 ライ ンであり，主としてデェレーションケーキ，マーブルケ 一キなど円形，柱状の比較的大きい製品を製造してい る. II-Group はコンベフ面高 $70 \mathrm{~cm}$ の 1 ラインであり, ショートケーキなどの小さな製品を製造する群である. 製品の大きさの違いは，先に記したように単位時間当り の流れ個数の違いをるたらすが，大きい製品では小さい 
製品に比べ 1 個当りの動作が多くなっている.

作業者 108 名の平均身長 と標準偏差は, $153.0 \pm 4.0$ cm であった．この数值の意味するところは，作業者の 身長が正規分布をするならば $68.3 \%$ の者が身長 149.0 $\mathrm{cm}$ から $157.0 \mathrm{~cm}$ のあいたにあることを示している. こらいった前提炕立ってそれぞれのコンペア面高に対す る身長比をるとめると，70cm コンペアでは身長此 $44 \sim$

Table 2. Assessments of height of conveyor-belt.

\begin{tabular}{|c|c|c|c|}
\hline & $N:$ & $\underset{(78)}{\text { I-Group }}$ & $\begin{array}{c}\text { II-Group } \\
(30)\end{array}$ \\
\hline Suitable & & 62.8 & $36.7^{*}$ \\
\hline Too high & & 7.7 & 13.3 \\
\hline Too low & & 16.7 & 33.3 \\
\hline No answer & & 12.8 & 16.7 \\
\hline
\end{tabular}

* Statistically significant at $p<0.05$. 47\%，75cm コンベアでは身長比 48～50\% であった

Table 2 はコンベフ面高について作業者の評価を示し たものである.「ちょらどよい」とする者は II-Group では 36.7\%，I-Group では 62.8\% であり両者間に差を 認めた（ $p<0.05)$ ．また，「低すぎる」という指摘は II-Group K 33.3\%, I-Group 16.7\% で II-Group に多 い傾向か誋められた。

I, II-Group のそれぞれの年龄，作業從事年数は Table 3 に示した. I-Group の平均年踰は 40.8土4.1 嵅, II-Group が 40.9土4.3 歳であり，作業從事年数は I-Group が 2.2 年, II-Group が 3.3 年であった.

\section{3. 頸肩腕, 背腰部の局所症状}

「仕事による疲労の翌日へのもちこし」は，翌日まで 「いつも」るこすとする者が $11 \%$ であり, I, II-Group 間では差を楒めなかった（Table 3).

慢性化したかたちで自筧される身体疲労部位の訴え率

Table 3. Incidence of reported localized fatigue in two groups of female assembly-line workers.

\begin{tabular}{|c|c|c|}
\hline & $\underset{(78)}{\text { I-Group }}$ & $\begin{array}{l}\text { II-Group } \\
(30)\end{array}$ \\
\hline Mean age \pm s.d. (years) & $40.8 \pm 4.1$ & $40.9 \pm 4.3$ \\
\hline Length of employment (mean years) & 2.2 & 3.3 \\
\hline Height of the conveyor $(\mathrm{cm})$ & 75 & 70 \\
\hline \multicolumn{3}{|l|}{ Complaints $(\%)$} \\
\hline Residual fatigue the next morning & 10.2 & 13.3 \\
\hline \multicolumn{3}{|l|}{ Complaints of localized fatigue $(\%)$} \\
\hline Hand right & 19.2 & 3.4 \\
\hline left & 1.3 & 0 \\
\hline Wrist right & 29.5 & 16. 7 \\
\hline left & 5.1 & 3.4 \\
\hline Arm right & 25.6 & 33.4 \\
\hline left & 3.8 & 6.7 \\
\hline Elbow right & 5.1 & 6.7 \\
\hline left & 1.3 & 0 \\
\hline Shoulder right & 26.9 & 46.7 \\
\hline left & 12.8 & 13.3 \\
\hline Neck & 19.2 & 20.0 \\
\hline Back & 20.5 & 20.0 \\
\hline Lower Back & 32.1 & $56.7^{*}$ \\
\hline Feet & 17.9 & 30.0 \\
\hline Knees & 3.8 & 6.7 \\
\hline Eyes & 12.8 & 23.4 \\
\hline
\end{tabular}

$* p<0.05$. 
Table 4. Comparison of percentages of female assembly-line workers having localized fatigue related to working hours and height of conveyor-belt.

\begin{tabular}{|c|c|c|c|c|}
\hline & \multicolumn{2}{|c|}{ I-Group } & \multicolumn{2}{|c|}{ II-Group } \\
\hline & \multicolumn{2}{|c|}{ Working hours } & \multicolumn{2}{|c|}{ Working hours } \\
\hline & $\begin{array}{c}1.5 \& 4.0 \mathrm{hrs} \\
(35)\end{array}$ & $\begin{array}{c}8.0 \mathrm{hrs} \\
(40)\end{array}$ & $\begin{array}{c}1.5 \& 4.0 \mathrm{hrs} \\
(5)\end{array}$ & $\begin{array}{c}8.0 \mathrm{hrs} \\
\text { (25) }\end{array}$ \\
\hline \multirow[t]{2}{*}{ Lower Back } & 4 & $17^{* * *}$ & 5 & 12 \\
\hline & $10.5 \%$ & $42.5 \%$ & $100.0 \%$ & $48.0 \%$ \\
\hline \multirow[t]{2}{*}{ Feet } & 2 & $12^{*}$ & 2 & 7 \\
\hline & $5.3 \%$ & $30.0 \%$ & $40.0 \%$ & $28.0 \%$ \\
\hline
\end{tabular}

${ }^{*} p<0.05,{ }^{* * *} p<0.001$. I-Group : $75 \mathrm{~cm}$ conveyor-height, II-Group : 70cm conveyor-height.

をTable 3 に示した. 腰, 右肩, 右腕の部位に共通して 吰え率が高くなっていた，I，II-Group 間で訴え率に差 が羿められた部位は腰部のみであった. ニンべフ面高が 低いII-Group では, 䁏部の訴えが $56.7 \%(p<0.05)$ と高くなっていた. そこで作業時間ならびに年龄との関 係について検討した. 表には示していないが，作業時間 を 90 分，4時間の 8 時間未满群（ $N=43$ 名）と 8 時間 群 $(N=65$ 名) に分けて身体疲学部位の訴充率を比較す ると，16の部位のうち腰部，むしの 2 部位に有意な差を 認めた。すなわち，8時間未満群の腰部の訴え率は 20.9 $\%$ に対し，8時間群は $43.1 \%(p<0.05)$ と高く, あし の訴充率は 8 時間未満群が $9.3 \%$ 飞対し，8時間群は $29.2 \%(p<0.01)$ となっていた. 年龄についてす 40 歳未满（N=42 名）と 40 歳以上 $(N=64$ 名) に分け て同様な比較をしたが訴え率には差が認められなかっ た.また, 50 歳未満 $(N=85)$ と 50 歳以上 $(N=21)$ との間にも差は認められなかった。

次に腰部，あしの訴え率を作業時間別，コンペフ面高 別にまとめ Table 4 そ示した. 腰部の訴え率は，8時間 未満群のなかではコンベフ面高が低い群に高く（ $p<$ 0.01)，コンベフ面高 $75 \mathrm{~cm}$ の群であってる作業時間が 長くなると訴え率が高くなっていた $(p<0.001)$. あし の訴え率はコンベア面高 $75 \mathrm{~cm}$ 群で時間とともに高くな っていた $(p<0.05)$.

\section{4. 疲労発症要因の自己評価}

作業者自身が問題ありとした，㝿労を強めた要因は Table 5 に示したとおりである.

I, II-Group k共通して高い指摘率の項目は，「手や 腕をくり返し使う」，「同じ姿樊が多い」であった，I, II-Group の間で指摘率に差が認められた項目は，「立 らつめである」( $p<0.001)$ ，「コンベア面高が合わな 以 $(p<0.001) ， 「$ 「ベフスピードが速すぎる」（p
<0.05)であり，いずれもコンベフ面高が低いII-Group に高くなっていた。

次に，年龄別 (40 歳末満上 40 歳以上の 2 群) では， 10項目の疲労発症要因の指摘率には差が認められなかっ たが，50 歳未満と 50 歳以上との閒では，50歳以上の高

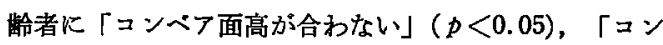
ベアスピードが速すぎる」（ $p<0.01 ）$ の指摘率が高く なっていた。 また，作業時間別 ( 8 時間未満と 8 時間群) では，先のI，II-Group 間で有意差を認めた項目に指摘 率の差を認めた。すなわち，「立ちつうめである」は 8 時 間未満群が $14.0 \%$ に対し， 8 時間群は $35.4 \%$ で高く

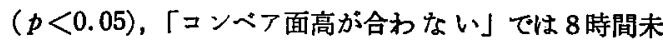
満 2.3\%，8時間群 $21.5 \%(p<0.05)$ ，「コンペアス ピードが速すぎる」は 8 時間未満 $7.0 \%$ に対し，8時間 群は $27.7 \%(p<0.05)$ であった.

作業時間-ンンベフ面高別に有意差が認められた 3 項 目の指摘率を Table 6 に示した. 「立ちづめである」は 8 時間群のコンベフ面高が低い群に高く $(p<0.05)$ ， 「コンペア面高が合わない」あ8時間群のコンベフ面高 が低い群に高かった $(p<0.05)$.

\section{5. 形肩腕，腰部症状による通院，治療経験}

頸有腕部㔚よび腰部の症状のため，これまでに医療機 関などに通院，治療した経験をるつ者は108名のうち 35 名, $34.4 \%$ であった。

それらについて医師の診断病名を整理すると，「手指， 腕のつかいいたみ」が最る多く11名, 次いで「腰痛症」 7 名,「腱豧炏」 4 名,「神経痛」 4 名,「筇肉痛」 3 名, 「頸腕症」3名，「疲れ」3名であった．むた，治療内 容は，「はり・条，湿布」の外用が最も多く，次いで注 射，服用などの薬物治療となっていた。

通院招よび治療経駩者の割合をコンベフ面高，作業時 間，年跉別に Table 7 に示した。 
Table 5. Main stress-causing factors of female assembly-line workers.

\begin{tabular}{lcc}
\hline & $\begin{array}{c}\text { I-Group } \\
(78)\end{array}$ & $\begin{array}{c}\text { Il-Group } \\
(30)\end{array}$ \\
\hline Repetitive use of the arms and hands & 52.6 & 43.3 \\
Holding arms and hands at a fixed level & 14.1 & 13.3 \\
Unnatural working posture & 11.5 & 26.7 \\
Static posture during work & 25.6 & 36.7 \\
Too much work & 11.5 & 10.0 \\
Sustained standing position for long period & 16.7 & $53.3^{* * *}$ \\
Lifting and holding heavy things & 21.8 & 33.3 \\
Poor layout of machines and tools & 2.6 & 6.7 \\
Unsuitable conveyor-belt height & 6.4 & $33.3^{* * *}$ \\
Work speed too fast & 14.1 & $33.3^{*}$ \\
\hline
\end{tabular}

${ }^{*} p<0.05,{ }^{* * *} p<0.001$.

Table 6. Main work factors causing stress in female assembly-line workers.

\begin{tabular}{|c|c|c|c|c|}
\hline & \multicolumn{4}{|c|}{ Working hours } \\
\hline & \multicolumn{2}{|c|}{$1.5 \mathrm{hrs} \& 4.0 \mathrm{hrs}$} & \multicolumn{2}{|c|}{$8.0 \mathrm{hrs}$} \\
\hline & $\begin{array}{c}\text { I-Group } \\
(38)\end{array}$ & $\begin{array}{l}\text { II-Group } \\
(5)\end{array}$ & $\begin{array}{c}\text { I-Group } \\
(40)\end{array}$ & $\begin{array}{l}\text { II-Group } \\
(25)\end{array}$ \\
\hline Sustained standing & 4 & 2 & 9 & $14^{*}$ \\
\hline position for long period & $10.5 \%$ & $40.0 \%$ & $22.5 \%$ & $56.0 \%$ \\
\hline Unsuitable & 1 & 1 & 4 & $9^{*}$ \\
\hline conveyor-belt height & $2.6 \%$ & $20.0 \%$ & $10.0 \%$ & $36.0 \%$ \\
\hline \multirow[t]{2}{*}{ Work speed too fast } & 3 & 0 & 8 & 10 \\
\hline & $7.9 \%$ & 0 & $20.0 \%$ & $40.0 \%$ \\
\hline
\end{tabular}

$* p<0.05$. I-Group : $75 \mathrm{~cm}$ conveyor-height, II-Group : $70 \mathrm{~cm}$ conveyor-height.

Table 7. Workers requiring medical treatment.

$\left.\begin{array}{rlll}\hline \text { Conveyor height } & (N) & & \\ \text { I-Group } & (78) & 18 & 23.1 \% \\ \text { II-Group } & (30) & 17 & 56.7\end{array}\right]_{* *}$

Working hours

\begin{tabular}{|c|c|c|c|}
\hline $1.5 \mathrm{hrs}$ & (16) & 2 & $12.5]$ \\
\hline $4.0 \mathrm{hrs}$ & (27) & 4 & 14.8 \\
\hline $8.0 \mathrm{hrs}$ & (65) & 29 & 44.6 \\
\hline
\end{tabular}

Age in years

$\left.\begin{array}{llrl}-29 & (9) & 2 & 22.2 \\ 30-39 & (33) & 9 & 27.3 \\ 40-49 & (43) & 12 & 27.9 \\ 50- & (21) & 11 & 52.4\end{array}\right] *$

$* p<0.05, * * p<0.01$.
コンベア面高が低いII-Group では 56.7\% の者が通 院・治噔経験者であり，I-Group との間に有意差が認め られた $(p<0.01)$. 作業時間 8 時間と 8 時間未満群との 間では，8時間群に通院・治療経験者の割合が $44.6 \%$ と高く，8時間未满群との間で差が楒められた（ $p<$ 0.01)。また，年龄との関連では 50 歳以上になると通院 ・治療释験者が $52.4 \%$ と高く, 50 歳未満群との間で差 が認められた $(p<0.05)$.

通院開始年度と通院までの從事期間との関係を Table 8 に示した。

1980，1981 年に通院を開始した者が多くなっていた。 通院までの期間は「 1 年以上 3 年未满」の者が $40.0 \%$ と多いが、「 1 年末満」の者る $25.7 \%$ と少なくなかった. 
Table 8. Length of employment at time of first medical treatment.

\begin{tabular}{|c|c|c|c|c|c|c|c|c|c|c|}
\hline & \multicolumn{2}{|c|}{-1 month } & \multicolumn{2}{|c|}{$-1 \mathrm{yr}$} & \multicolumn{2}{|c|}{$1-3$ yrs } & \multicolumn{2}{|c|}{3 yrs or more } & \multicolumn{2}{|r|}{ Total } \\
\hline 1976 & & & & & 1 & & & & 1 & $2.9 \%$ \\
\hline 1977 & & & & & & & 1 & & 1 & 2.9 \\
\hline 1978 & & & & & 1 & & 1 & & 2 & 5.7 \\
\hline 1979 & & & 1 & & 1 & & 2 & & 4 & 11.4 \\
\hline 1980 & & & 3 & & 3 & & 6 & & 12 & 34.3 \\
\hline 1981 & 2 & & 3 & & 8 & & 2 & & 15 & 42.9 \\
\hline Total & 2 & $5.7 \%$ & 7 & 20.0 & 14 & 40.0 & 12 & 34.3 & 35 & $100.0 \%$ \\
\hline
\end{tabular}

\section{V. 考察}

労傎省の統計 ${ }^{14)}$ とよると、コンベアなどの生産工程作 業に従事する婦人の割合は事務作業についで多いことが 示されている. 多くの婦人が生産工程作業に就労してき た背景には，技術革新のすとで作業の分業化と細分化が 進み，作業手順が規格化され，動作が単純化されてきて エネルギー代謝率でいら軽作業になってきていることが 指摘される.ささらK，パート雇用など，労務管理面や経 済面でのかねあいから，婦人の展用が拡大してきた側面 るみのがせない.

しかし，このような婦人を中心とした作業現場では， 他の職場と比へてて相対的に労働条件中作業環境条件が充 分に整備されていない上に，作業者にとっては家事や育 見からくる負担も少なくないことが指摘されている

調査対象とした工場の作業者は，ほとんどが女性であ ク，そのうちの 9 割以上にあたる者がパート雇用であっ た. 30 歳代， 40 歳代の中高年龄層の主婦が中心である. 対象工場で, 頸肩腕障害や腰痛などの健康障害が職場の 問題として取りあげられてきた経過をみると，職場の日 常的な健康管理活動を通して把握されたるのではなく， 欠勤のために提出されてきた診断書に「頸肩腕症」「「腰 痛症」「腱䩗炎」といった病名が多くなったことが対策 の契機になっていた，中高年齢㬝の女子は，同年跲層の 男性飞比べ体格，体力その他の機能で性差をるち，さら に加龄によって感覚器, 運動機能の低下をはじめ, 有病

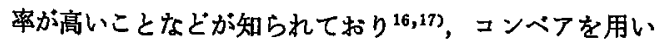
た流れ作業侍徴的な速度追随作業においては，中高年 路層の作業者への負担はより大きくなっていることと考 亮られる。

疲学発症要因の自己評価の結果には，コンベフ面高に 関係なく「手ゃ腕をくり返しつから」，「同じ勢が多 い」といった動作，姿赖の負担が指摘されていた，低い
コンベフ面高や作業時間の因子により「立らつかめであ る」,「コンベア面高が合わない」といった指摘が增大 し，反復動作や特定の姿勢を保持するため，局所筋群の 静的筋収縮による筋負担がコンベア面高，作業時間因子 によってより強められている状況があると考えられる。

また，頸肩腕部や背腰部の症状発現を，作業姿劭を規 定するコンペフ面高，作業時間，年龄などとの関連で検 討すると，コンべフ面高の高さが「らょらどよい」とし

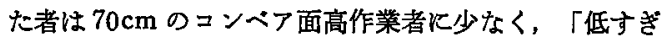
る」とした者が多く，働きにくい状況を訴えていた。こ のことは，作業者にとってコンベア面高の低すぎが，腰 の負担を強めており，75cm のコンベて面高でも作業時 間が長くなることにより腰，下肢の負担が強くなること を示しているといえよう。

立位作業での好適な作業面高は肘高や手作業の種類に よって決められてくるが ${ }^{18)}$ ，身長比との関連では 55 60 \%前後の範囲内にあると考えられている ${ }^{18)}$ ，本作策での コンペア面高に対する身長比は，平均身長（摽準偏差） から多くの者が 48 50\% の範囲にあると考觉られる. このことからも，コンベ面高が低位でそのことからく る前傾の姿勢負担が強くなっていることが考兄られる。

流れ作業は機械のスピードによって作業速度が決めら れて拈り，そのためにややすすると姿勢変換の自由度が 小さくなり，姿势負担が強まることが知られている ${ }^{19,20)}$. コンベフ面高などの人間工学的条件の不備が加かること により，局所障害の発生が促進されやすくなるといるよ 5 .

次に，疲労発症要因を年龄別にみると，50歳をこえる と「コンペアスピードが速すぎる」，「コンバ面高が合 わない」といった指摘が高くなり，コンベアスピードゃ 一連続作業時間に対する予防対策が人間工学的条件の整 備ととすに必要であることを示している.

頸肩腕部や腰部症状のためにこれまでに通院・治療 
をしたことがある者は、コンベア面高, 作業時間や年蛤 によって差がみられているが，作業時間が 8 時間未漓の 90分や 4 時間作業者群でも通院・治潦経験者の㓶合は少 なくない.このことは、コンベア作業に従事する者の負 担軽減策がパート作業者に対しても行われる必要がある ことを示している.

わが国で頸房腕障害が社会問題化されてきた時期は， 1960年以降である. 当初, 電算機の導入に伴って専門職 化されてきたキーパンチャーなどその発症が認めら れてきたか，その後，スーパー店のチェッカーや精密機 器等の組立作業者などの生産現場にも同様な症状, 障害

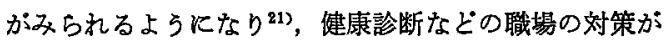
とられるようになってきた. 調查対象工場では 1974 年 にコンベフ作業者に「腱䩗炎」と診断された事例をるっ ていたにあかかわらず, その後, 健康診断も含めてとく に対策は何もされないまま至っていた，洋菓子製造で は，工業的生産方式そのるのが比較的新しいとはいうる のの, 当時, コンベアなどの生産方式による作業負担上 の諸問題を把挃することは可能であり，その意味で，職 場評価や煡康評価の職場での基本的健康管理活動が不十 分であったといえる. また，工場規模の桩大や生産量の 増大に対応させるため，半熟練作業者を多量に導入した ことが，障害の多発をすたらした一要因たとも考えられ る.

今後の対策としては, 就労前の茟康診断や作業者の初 期教育, 訓練期間の確保ならびに作業者の訴えを早期に 発見し，労働諸条件の改善に結びつく健康管理体制の整 備が必要である.それとともに，作業動作や作業姿势に よる労働負担の軽減のためにコンベア作業の一連続作業 時間の規制, コンベフ面高の改善，休息の挿入，休䄸室 の設䁂など，総合的な予防対策が必要であると考えられ た.

\section{V. お りに}

コンベアシステムによる洋菒子製造の仕上げ女子作業 者に頸, 腕, 手, 腰の症状の訴えが頻発し, 頸肩腕障害 や腰痛で通院，治療をした者が発生したことから，労働 条件, 作業負担と局所症状との関連で労働衛生学的調查 研究を行い, 次の結果を得た。

1)この工場のコンベア作業では，中腰前傾の立業姿 浆と上肢の反復動作, ならびに視覚, 神経の集中が要求 されており，局所筋の負担とともに神経・感覚系の負担 が大きいと考えられた.

2）局所症状を強めた原因は，「手・腕をくり返し使 ら」,「同じ姿勢が多い」が作業者の指摘として高くなっ
ていた. コンべフ面高が低い条件や作業時間が長くなる と「立ちつ゚めである」,「コンベア面高が合わない,「コ ンベアスピードが速すぎる」という指摘が高まってい た.

3) 頸肩腕部や腰部症状で通院，治療をしたことがあ る者は、コンベフ作業従事者の $32.4 \%$ にあなっていた。 コンペア面高，作業時間，年撂により通院，治療者数の 違いがあったが，作業時間が 90 分，4時間の短い:ー ト作業者であってるその割合は決して少なくなかった。

4) 頸肩腕部や腰部症状は，コンベフ面高による立位 前傾姿势や流れ作業からくる上肢の反復動作，同一姿器 の保持などの拘束性の強さが主要な要因としての役割を るち, 年龄や作業時間, コンベア面高などの人間工学的 な条件の不備が症状助長, 増悪要因としてからみあいな がら発症に至ったと考えられた。

以上の結果に基づき，健康管理体制の充実や労働諸条 件の改善の必要性について述へた。

稿を岕わるにあたり，とりまとめにあたってこ助言をいただ いた中迫勝先生（関西医科大学衙生学教室）に謝意を表します。

\section{文献}

1) 斉藤 一：単誦労働に関する研究一技術革新々単調労

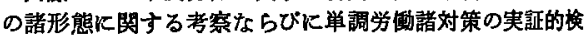
矿, 労働科学, $49: 47-88,1973$.

2) Haider, M. : Psychophysiological studies on stress and machine-paced work, in Machine Pacing and Occupational Stress, 303-310, Taylor \& Francis Ltd., London, 1981.

2) Kano, H. : Some problems on assessment of work load of vigilance, keypunching and conveyer task in the practical field of Japan, J. Sci. Labour, 44: $1-9,1968$.

4) 小山内博 : 㴗痛症と頸眉腕症候群の発生要因, 診断, 治 療，予防に関する研究，労俨科学，55：83-100，1979.

5) Maeda, K.: Occupational cervicobrachial disorder and causative factors, J. Human Ergol., 6: 193-202, 1977.

6) 前田勝義：コンベア流れ作業における頸肩腕障害一羽電 機器メーカーにおける事例, 労做の科学, $29: 26-33,1974$

7) 前田勝義，平山八郎，高松誠：炠巻きが二制造工場 の女子流れ作業者にみられた頸同腔障害, 主桠医学, 19： 8-21, 1977.

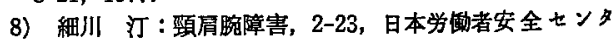
一, 東京, 1975 .

9) 松本明子：松下電器のコンベフ流れのなかで, 現代の労 働と健康を守る権利，128-144，法律文化社，京都，1979.

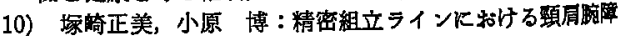
害への対応, 学䣦衙生, $24: 27-30,1983$.

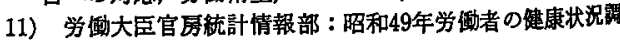
㚗報告, 1975 .

12）逸見てる子：一ェレクトロニクス工㧹における産莱整生 
的研究（第 1 報）母性保健管理の実態一とくにコンベフ作 莱を中心と乙て, 北関東医学, $26: 19-28 ， 1976$.

13）迁井字一：洋菒子の自主的街生管理について, 食品衛生 研究，32:517-527，1982.

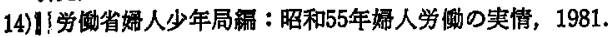

15）渡辺明产，大西徳明，進藤弘基，酒井一博，齐藤 一：

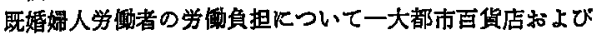
自動車部品組立作辣女子従羑員についての事 例, 労働科 学, $54: 189-203,1978$.

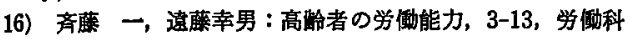
学研究所, 川䓫, 1980.
17）勝木新次：中高年秢者の体力と学倒，51-89, 労憉科学 研究所, 川崎, 1978.

18) Grandjean, E.: Fitting the task to the man, 41-43, Taylor \& Francis, London, 1981.

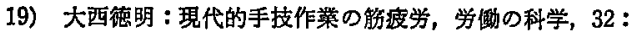
19-25, 1977

20) Onishi, N.: Muscle load and fatigue of film rolling workers, J. Human Ergol., 6: 179-186, 1977.

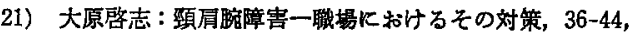
労働基溥調查会, 東京, 1979 .

著者への通信先：近藤雄二, $=634$ 㮒原市四条町 840 奈良県立医科大学衛生学教室 Reprint requests to Department of Hygiene, Nara Medical University, Shijo-cho, Kashihara, 634 Japan (Y. Kondo) 